Valóságos könyvtár - könyvtári valóság. Könyvtár- és információtudományi tanulmányok 2016. Szerk. Kiszl Péter, Boda Gáborné Köntös Nelli.

Budapest, ELTE BTK Könyvtár- és Információtudományi Intézet. 2017. 47-55.

\title{
THE MODERN ARCHITECTURE OF UNIVERSITY LIBRARY BUILDINGS - AN EFFECTIVE MARKETING TOOL ${ }^{*}$
}

\author{
SilVia STASSELOVÁ \\ Pozsonyi Egyetemi Könyvtár, főigazgató
}

\begin{abstract}
ABSZTRAKT
Az egyetemi könyvtárak modern épületei nemcsak az oktatás és a kutatás számára fontos minőségi hátteret biztosítják, hanem nagyon hatékony marketingeszközök is. Sok sikeres egyetem csábítja potenciális hallgatóit a kampuszán található modern és progresszív egyetemi könyvtári épülettel. A világon számos egyetem vált ismertté köszönhetően az egyetemi könyvtári épületeik különleges építészeti megoldásainak, ami bizonyos esetekben sokkal értékesebb, mint az új könyvtári épület létrehozásába fektetett kezdeti beruházás. A tanulmány az egyetemi kampuszok szívében található különféle modern könyvtári épületek egyedülálló felépítését mutatja be: a Delfti Műszaki Egyetem Egyetemi Könyvtára (Delft, Hollandia); az Országos Műszaki Könyvtár a Cseh Műszaki Egyetem kampuszán (Prága, Csehország); a Ružomberoki Katolikus Egyetem Egyetemi Könyvtára (Ružomberok, Szlovákia); és a Bécsi Közgazdaságtudományi Egyetem Egyetemi Könyvtára (Bécs, Ausztria). A 21. század az információ koraként ismert, de a könyvtári terek reneszánszát is elhozta minden könyvtárhasználónak. A könyvtárhasználók számára a könyvtári terek rendkívül értékessé kezdenek válni a külső stresszfaktorok ellensúlyozásában és a progresszív tanulási központok létrehozásában.
\end{abstract}

\section{The University Library in Bratislava}

At the beginning I would like to introduce the University Library in Bratislava, ${ }^{1}$ which is the oldest research library in Slovakia located in three historical buildings at the heart of Historical Centre. These buildings went through a reconstruction from 2002 to 2006 at the amount of approximately 19 million EUR.

University Library in Bratislava is the largest and the most visited Slovak research library. It was founded as the library of the Slovak University in 1919, but it has never become an integral part of the university, what is very interesting that we do not have any official connections to the University of Comenius even if our history is running together. In 2019 we will celebrate our 100 years' anniversary, so very soon, in three and a half a year. So, we have to prepare ourselves very well for this important event. This library served as the National Library in addition to its academic functions from the very beginning since 1919 until 1954. It is managed and financed by the Slovak Ministry of Culture.

* Az előadást lejegyezte Adolf Adrienn, szerkesztette és kiegészítette Barátné Hajdu Ágnes. 


\section{Silvia STASSELOVÁ}

All three main library buildings are protected historical monuments. And what is interesting: one of the library buildings is the historical palace of the Hungarian Royal Chamber which was built by the order of the queen Maria Theresa in 1751-1753. This historical palace became the seat of the Hungarian Diet - or the Hungarian Parliament in other words - in the $19^{\text {th }}$ century. The Hungarian Parliament used to have meetings here from 1802 to 1848 , so in the $19^{\text {th }}$ century. Another important building or extraordinary building we have is the historical building of the old monastery Clariseum. Two palaces are connected. The palace on the left has glass roof, and we have also two internal gardens. These internal gardens we have in the very heart of the historical city of Bratislava - or Pozsony as you know it in Hungarian. The following historical picture of the building of the Hungarian Royal Chamber on the left (Figure 1 and Figure 2), and Michael's Gate tower - it is up on the top of the street where this building is located and now it belongs to the library.

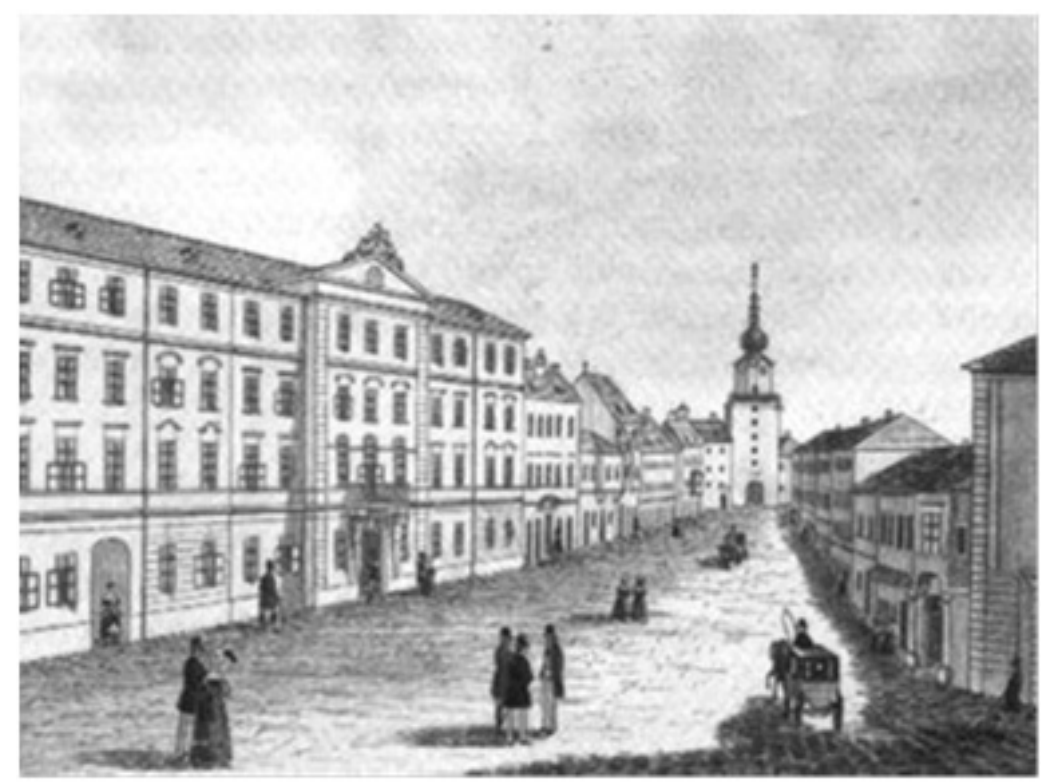

Figure 1: The Hungarian Royal Chamber on the left

There is the main entrance to the director's office and the old monastery. The church does not belong to us, but the monastery, the rest of the building, is serving the library and its users. And the third palace we have is the Pauli Palace, which was also rebuilt. And this is some moments from the interiors of the library before its first reconstruction in 1950 . 


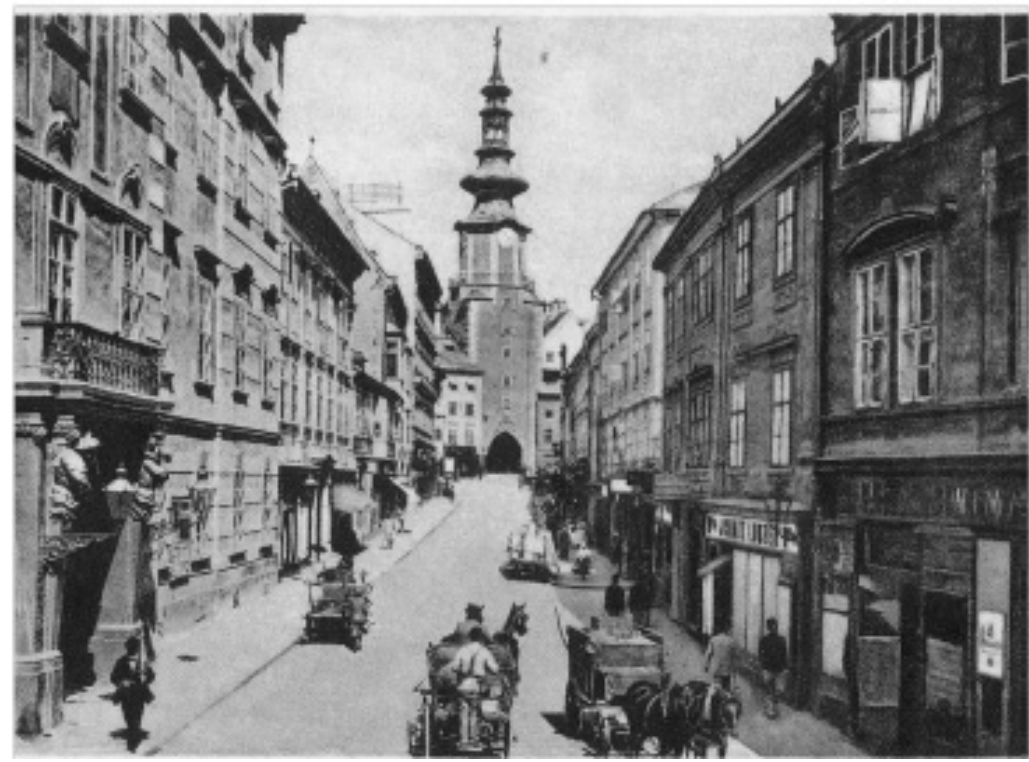

Figure 2: The Hungarian Royal Chamber

In the middle of the last century it went through a huge reconstruction and since then just 10 years ago was the second stage.

Just to compare how the building was looking like before the reconstruction: this is the internal square of the Pauli Palace where you can see some librarians and some musical events, and now it is after the reconstructions (Figure 3). The square which was open-air before now became internal baroque square with glass roof, and many interesting events are being held here, also conferences and we are also very welcome to people who come to Bratislava to see our historical building.
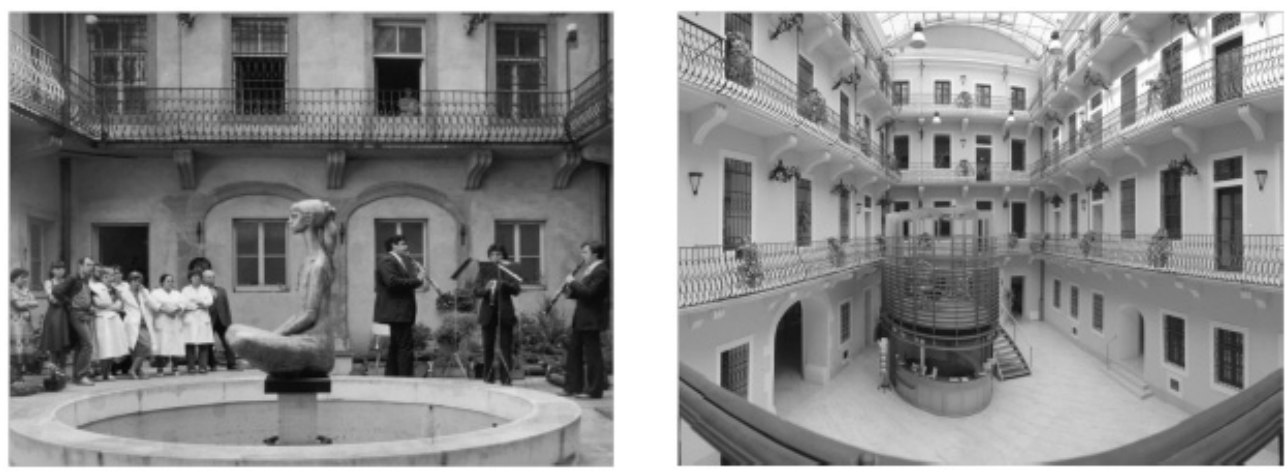

Figure 3: The Pauli Palace before and after the reconstruction

It makes a very nice atmosphere for this internal square for the users. 


\section{SiLVIA STASSELOVÁ}

There is the Liszt pavilion, in 1720 Franz Liszt played here a concert, or at least they say he was having a concert here. So, this was the previous music pavilion before the reconstruction and now you can see how it looks like after the reconstruction (Figure 4). This is one of the most beautiful views on the Bratislava castle, so this is really a wonderful view from our historical garden on the monuments of the historical city. Now it is closed to the public, just users can use it and mostly in the summer, but I am thinking - as the new general director - on opening our buildings at least in part for the tourists and people who are not registered, because really we have to be an open institution not closed that much as we are in the present.
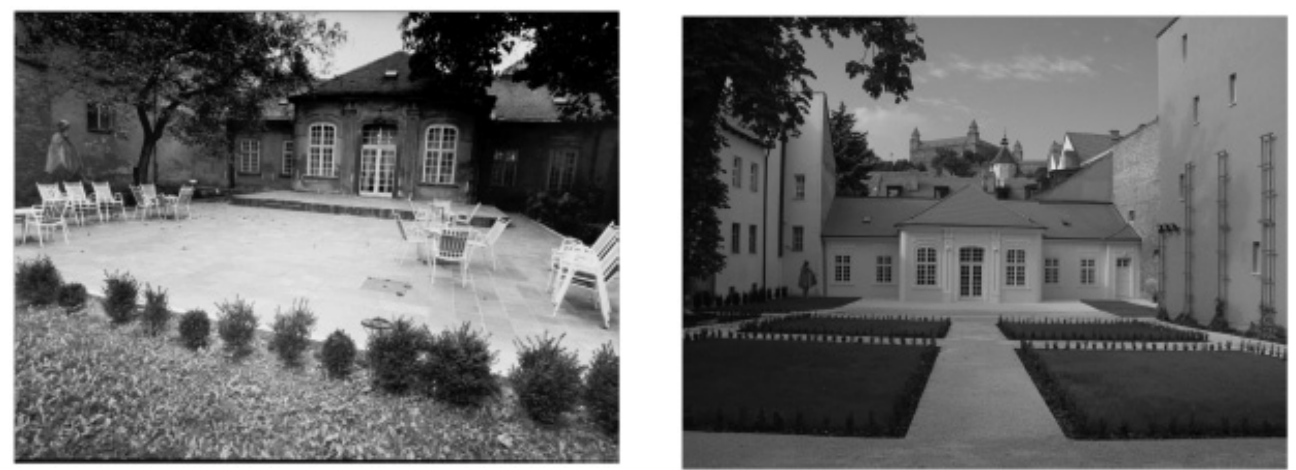

Figure 4: The Liszt pavilion

We are open for the users, but for the tourist not very open until now. The monastery is also a wonderful building which has an internal square. And here are the two neighbouring palaces: the Pauli Palace and the palace of the Hungarian Royal Chamber. They are connected, and you can walk inside and do not have to go out to the street, or at least librarians do not have to, but there are some barriers for users, because at the Hungarian chamber there is the director's office mainly and some administration offices. Behind the main entrance we became a very modern library; we have a lot of IT technologies, books and modern equipment. There is the lecture hall we have in the underground, and new storage which was built at the Liszt garden. The new library building is very popular and well visited from the public and the official audiences, too. One month ago we had a very important guest at our library. The general secretary of the United Nations visited the university library on the $19^{\text {th }}$ October 2015. Mr. Ban Ki Moon visited more historical sights of Slovakia, but he came to the library to see the very valuable Bašagić-collection of Islamic manuscripts. He was very much impressed by these historical manuscripts; some of them were dated to the $12^{\text {th }}$ century, so they are very valuable and we are very happy to own them. They are part of the UNESCO world heritage.

Now we come to the main part of the presentation which is about the modern architecture of university library buildings as an effective marketing tool. Modern architecture of 
university library buildings does not represent any important high quality background for education and research only, but also a very effective marketing tool.

\section{Additional university library buildings}

Many successful universities influence their potential students by modern and progressive university library buildings located at their university campuses. Numerous universities in the world became well-known thanks to an exceptional architecture of their university library buildings. The $21^{\text {st }}$ century is well-known as the information age, but it also brings the renaissance of a library space to all library users, especially now when there are a lot of stress factors outside and these libraries can create progressive learning hubs. This presentation documents a unique architecture for exceptional modern library buildings located at the heart of university campuses which became symbols of the universities. The selection was made by me from my archive, because I made all of the photographs about these buildings. Of course there are much nicer and more beautiful university buildings all over the world, but at least these I really visited and I can comment on what is really interesting on these architectural solutions.

\section{The Catholic University in Ružomberok}

The first university library at the north of Slovakia: It is based in Ružomberok, where the Catholic University is placed (Figure 5).
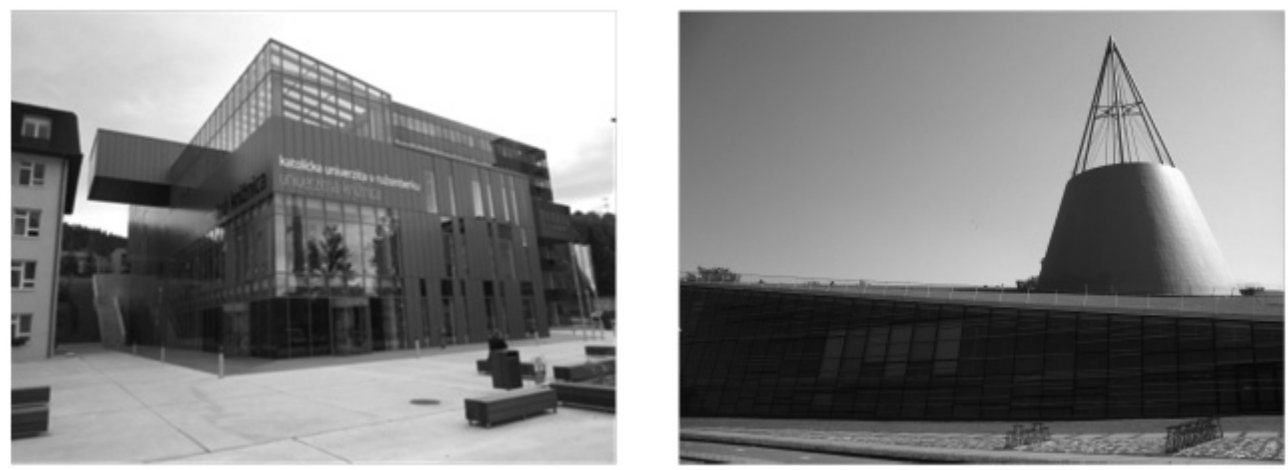

Figure 5: University libraries in Ruð̌omberok and Delft

Opening of this library building was on $25^{\text {th }}$ September, 2013. This library became a symbol of the catholic university, and what is very interesting it was built from volunteer donations of individuals and legal entities. These donations were collected at the amount of nearly 3 million EUR. From this amount the library was built and also from some other fund-raising support, but this success of fund-raising campaign exceeded many expectations and served as a major marketing tool for the nation-wide promotion of the Catholic University in Ružomberok raising the visibility of its activities. There is some information about the library building: different colours have been used on the 


\section{SILVIA STASSELOVÁ}

floors in order to facilitate users' orientation in the building as an effective way how to shorten the time necessary to gain the information-sources they are looking for. The library offers creative spatial design allowing its users to choose dynamic or silent zones for their study. It has comfortable seats and sofas, and offers good facilities for relaxing or also having creative discussions in small groups. The library has 7 floors, 2 silent study rooms, 1 computer study room, conference room and lecture hall. Users can use the university library open space, all computers located in the library. They can borrow notebooks and they can also bring their own pieces to the library. Wi-Fi is available everywhere. There are many self-check facilities, biblioboxes, copiers, book scanners. There is also a bookstore and café available in the building. And all holdings are using Radio Frequency Identification (RFID). The building is situated in the middle of the campus. It has a very modern structure and the various coloured floors helping users in orientation in the building. It is a very open space, also the glass walls open the space, you can see everywhere from the floors. They are using a very modern way of information systems. There are some sofas in front of the bookstore, computer study room for creative discussions of users. They are really welcoming. It is close to High Tatra Mountains, maybe one hour from there. These are the lecture halls and individual study places. The interior is very variable and flexible. There are separated silent study rooms. It is important because many libraries I have visited start to organize such places; they divide dynamic and silent zones. The information system area in this new library building is very interesting, because they organized the interior like it has small squares and streets, for example they have a Vatican square or Andrej Hlinka street. Sometimes users can be oriented by librarians just to 'follow the street or square which is inside the library.' Very nice, dominant parts of the library are the artistic masterpieces inside its interior. These are the navigations at the streets and squares and this is a masterpiece of art which is high and connects three floors and it is a main catholic pray.

\section{The Technical University Library in Delft}

This library was opened in 1998 like a symbol of modern university library building. The architect office which designed it was Mecanoo Architecten. It is in the middle of the campus. Before the library was built the campus had a dominant building, where is the main lecture hall of the technical university of Delft, the main aula, which is looking a little bit like a frog. Before the project of the new library they were thinking about the idea how the building should look like and there is a proverb that 'frog needs grass', so the library was projected with green roof. It is a kind of a grass hill, the library is inside. It is one of the students' favourite places, where they can relax during their study days if they have free time. The entrance looks like a secure entrance, but if you go into the library you are very much surprised by its high ceiling. It looks like a cathedral of knowledge or something like that. If you go inside this green hill and inside you are fascinated by the huge space and high ceilings. One of the most interesting symbols of this library is the four-floor-high shelf system which you can walk through by using the stairs up 
and down. It is beautiful, it looks like an artistic piece. There is also a play of the lights in the evening. It has blue walls, a wonderful look at the main wall, just in the opposite of the main entrance. The main symbol of this library is a concrete cone with a metal tip running from this grass hill. It looks like an Indian tepee somewhere on the prairie, because you know the Netherlands is the country of lowlands, so any grass hills is very much interesting for Dutch people, therefore this university library became a very much attracted place. There are individual study places inside, and it also gives daylight to the library from outside. Users can see each other from one floor to the other.

\section{The National Library of Technology in Prague}

In 2009 another nice building of university library was opened. It has similarities with the library where I come from. This National Library of Technology (Figure 6) is not connected to the Czech University of Technology in Prague, so it is an independent research library, but it is located in the heart of the university campus and is very much used by university students very much the same as our library, because we are in the centre and most of our users are students. It was opened on the $9^{\text {th }}$ September, 2009. It was designed by Czech architects, and it was given many awards, for example Building of the Year in 2009, Outstanding Concrete Structure, Library of the Year. There is open space inside. On the façade you can see the information, it is wide: 263 meters.
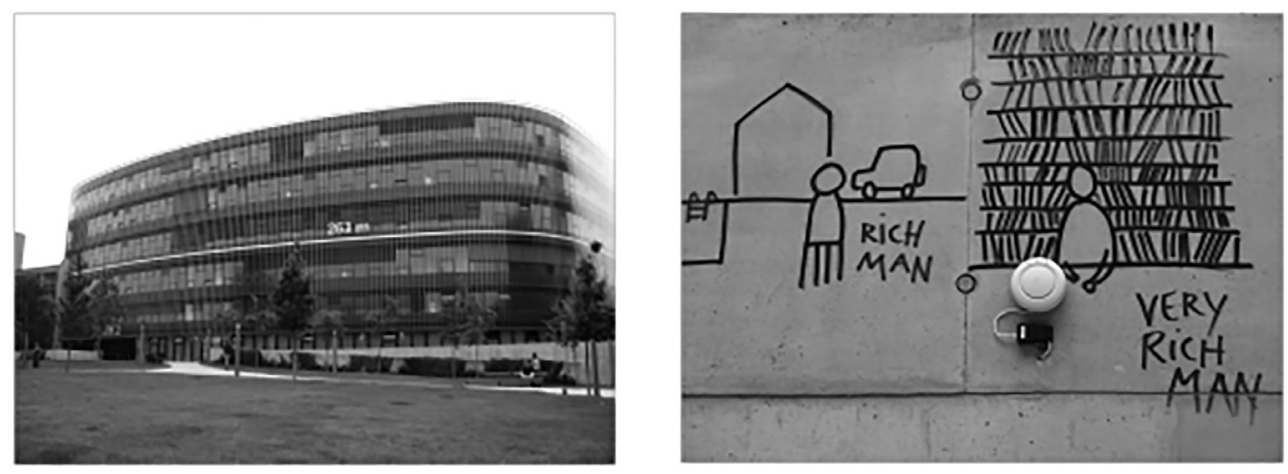

Figure 6: The National Library of Technology in Prague

This is a very nice way to promote the library, which is a technical one. The interior really represents its users. The main entrance is open for public, not just for users, but for everybody. All the rest of the library where users have possible access is connected to many staircases and the open atrium. You can see from one floor to the other, so it has a very open structure. The library is very famous and visited with the coloured floors, which is not the artistic idea, but it is really dynamic, and shows the statical pressure on the floor for those who are interested in statics. It is in the middle showed by the red colour, and then closer and closer to the wall the pressure on the floor is smaller and smaller. This is great for civil engineering students, when they are coming to the library, 


\section{SiLVIA STASSELOVÁ}

they can see how it really works, but it is a beautiful interior design as well. There are artistic masterpieces on the walls in the atrium: 200 drawings of Dan Perjovschi, who is a famous Romanian artist. These paintings are very funny and very controversial. Many people like them, but many do not. But most of them are very famous among the users. It became also one of the symbols of the library. You can see many funny pictures and caricatures which really promote the library. This is the way how to make it interesting and famous. For example, very rich man is the one who owns the books.

\section{The University Library of the Vienna University of Economics and Business}

The University Library of the Vienna University of Economics and Business (Figure 7) was opened in 2013. The architect was Zaha Hadid, a very famous British architect. The whole campus of University of Economics and Business was built during 4 years after 6 years design for 12 billion EUR, which is a huge amount of money. This is the largest university campus in Europe. The library was designed and built between 2008 and 2013. It is a huge beautiful library, and it looks like a spaceship inside. It is beautiful, a really extraordinary interior design; there are a lot of attractions, e.g. the cafeteria which looks like a library, etc. It can be interesting not just for students but also for architects and researchers. From here you can see part of Vienna and the Prater.

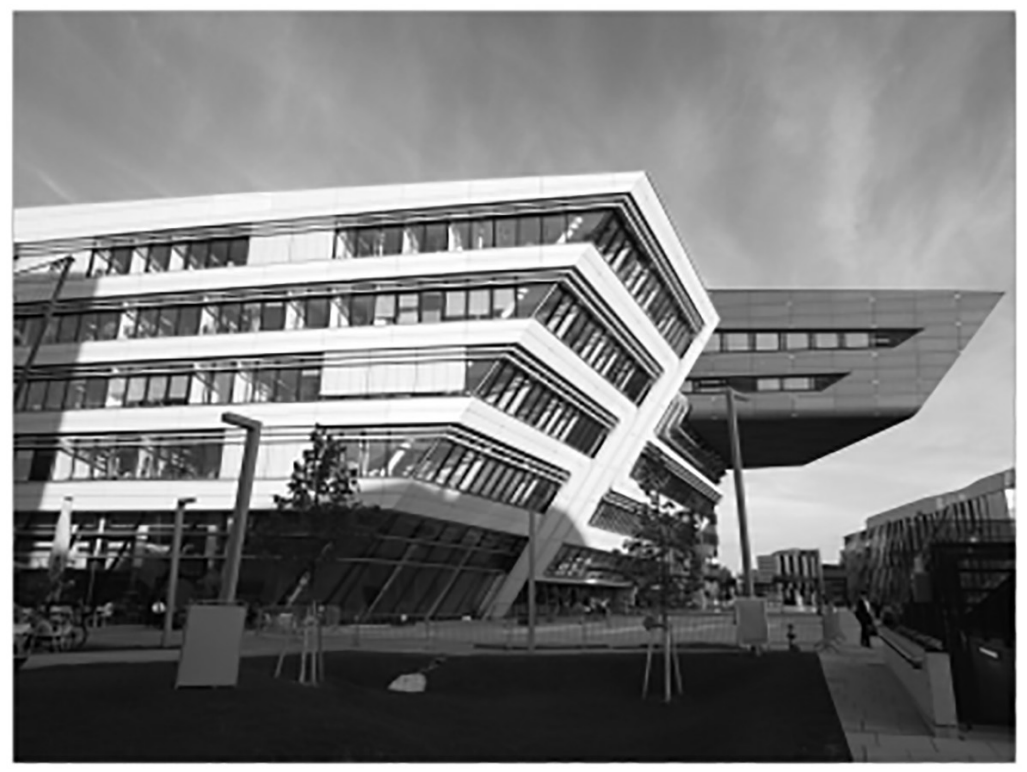

Figure 7: The University Library of the Vienna University of Economics and Business

The library building has individual study rooms for learning alone; and the rest of the library is very dynamic, open. There is a book store open for users, a cafeteria. There are modern technology and wonderful design with beautiful furniture. 
It is very important that university library should become the symbol of the university, so the top management of the universities should invest to the libraries, because they can really help to promote the university and to gain more and more students interested in studying at the university. These marketing outcomes are more valuable than the initial investment to the reconstruction or the new library buildings. It is very crucial to emphasise that it is not a lost investment, but the return always goes back to the university.

\section{References}

${ }^{1}$ Website of the University Library in Bratislava: www.ulib.sk [10 September, 2016]

${ }^{2}$ The old pictures are from the collection of the University Library in Bratislava, the author of the study provided them for us. The rest of the pictures were created by the author herself.

Silvia Stasselova a pozsonyi Egyetemi Könyvtár főigazgatója, a Szlovák Könyvtárosok és Könyvtárak Egyesületének elnöke. 